\title{
S-アルキルシステインおよびそのジペプチド誘導体の合成
}

\author{
永井外夫, ${ }^{1 a)}$ 福原 裕, $^{1 b}$ 㫻田幸蔵 ${ }^{1 c)}$ \\ 北陸大学薬学部, ${ }^{1 a}$ 金沢大学薬学部, ${ }^{1 b}$ 近畿大学薬学部 ${ }^{16)}$
}

\section{Synthesis of S-Alkyl Cysteines and Their Dipeptide Derivatives}

\author{
Sotoo Nagai, ${ }^{1 a)}$ Yutaka Fukuhara, ${ }^{1 b}$ and Kozo OKada ${ }^{1 c)}$ \\ School of Pharmacy, Hokuriku University, ${ }^{1 a}$ ) Faculty of Pharmaceutical Sciences, \\ Kanazawa University, ${ }^{1 b}$ ) and Faculty of Pharmaceutical Sciences, \\ Kinki University ${ }^{1}$ )
}

(Received June 23, 1979)

\begin{abstract}
A series of S-alkyl cysteine- $(\mathrm{R}=\mathrm{Me}, \mathrm{Bzl}, \mathrm{All})$ and dipeptide derivatives with the sequences Cys(R)-Ser and Ser-Cys(R), fully or partially protected or free at the terminals, were prepared for use in a study of antioxidative action against the autoxidation of linoleic acid.

N-Acyl-S-alkyl cysteins $(\mathbf{1}-\mathbf{5})$ and S-alkyl cysteine methyl esters $(\mathbf{6}-\mathbf{8})$ were prepared from the corresponding S-alkylcysteine in the usual manner. Further, the former were condensed with serine methyl ester and the latter with $\mathrm{N}$-acyl serine by the mixed anhydride or DCC method to give BOC- or Z-Cys(Bzl)-Ser-OMe $(\mathbf{9}, \mathbf{1 0})$ and BOC- or Z-Ser$\mathrm{Cys}(\mathrm{Bz} 1)-\mathrm{OR}(\mathbf{1 5}, \mathbf{1 6})$, respectively. Saponification and/or acidification of these peptides led to the partially protected peptides $(11,17-19)$ or free peptides $(12,20)$. With the same procedure, cysteinylcysteine derivatives $(13,14)$ were also prepared.
\end{abstract}

Keywords-S-alkyl cysteines; dipeptides containing cysteine and serine; $\mathrm{N}$ acylation; esterification; peptide synthesis; antioxidative activity

アミノ酸の油脂ないし不飽和脂肪酸に対する抗酸化性についてこれまで多くの研究が行なわれているが,2) 抗酸 化力の測定法や測定条件によって結果が左右され，報告者によって異なった結果が得られている。しかし一般に 異項環アミノ酸（トリプトファン，ヒスチジン）と含硫アミノ酸のうちでメチオニンに著しい抗酸化効力のある ことが共通して認められている.これに対し含硫アミノ酸であるシステインの抗酸化性についてはこれまでに相 反する結果が得られている．名武ら゙) はシステインがリノール酸の自動酸化を促進することを見出しその機構を 考察した：これに対し小嶋ら ${ }^{4)}$ はリノレン酸の自動酸化に対してシステインエステルがメチオニンより優れた抗 酸化作用を有することを認めている。

われわれは $\alpha$ トコフェロール ( $\alpha$-Toc) とブチルヒドロキシトルェン (BHT) の抗酸化作用に対するアミノ酸 の影響を調ベたところ，システインは $\alpha$-Toc に対して相乗効果を示すが BHT に対しては拮抗的に働くことを 認めた.5

今回, 油脂の自動酸化および上記の抗酸化剂に対するシステインの作用を明確にし，併せてその構造と作用相

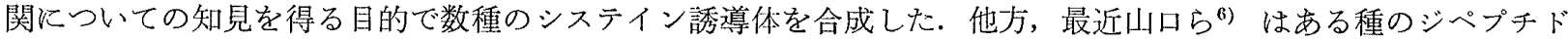
がそれを構成するアミノ酸より大きい抗酸化力をもつことを報告している， $\alpha$-Toc と BHT のいずれに対しても

1) Location: a) Kanagawa-machi, Kanazawa 920-11, Japan; b) Takara-machi, Kanazawa 920, Japan; c) Kowakae, Higashi-Osaka 577, Japan.

2) R. Marcuse, Natuve (London)，183，836 (1960); 満田久輝，安本教伝，岩見公和，栄養々食糧，19，210 (1966); M. Karel, S.R. Tannenbaum, H.D. Wallance, H. Maloney, J. Food Science, 31, 892 (1966); 山 口真彦，油化学，25, 249 (1976).

3）名武昌人，団野源一，栄盖之食糧，26，251 (1973).

4) 小嶋 操, 末次良子, 日本薬学会第 93 年々会, 東京, 1973 年 4 月.

5）岡田幸蔵，永井外夫，番匠悦子，日本薬学会第 94 年々会，仙台，1974 年 4 月，衛生化学，印刷中.

6）山口直彦，横尾良夫，藤巻正生，食品工誌，22，425 (1975). 
TABLE I. S-Alkyl Cysteines $(\mathbf{1}-\mathbf{8})$

\begin{tabular}{|c|c|c|c|c|c|c|c|c|c|}
\hline \multirow{3}{*}{$\begin{array}{l}\text { Compd. } \\
\text { No. }\end{array}$} & \multicolumn{2}{|c|}{$\begin{array}{c}\mathrm{R}^{2} \\
\mathrm{R}^{1}-\mathrm{Cys}-\mathrm{COOR}^{3}\end{array}$} & $\begin{array}{l}1: \mathrm{R}^{1}=\mathrm{Ac} \\
2: \mathrm{R}^{1}=\mathrm{Ac} \\
3: \mathrm{R}^{1}=\mathrm{Bz} \\
4: \mathrm{R}^{1}=\mathrm{Z}\end{array}$ & $\begin{array}{l}\mathrm{R}^{2}=\mathrm{Me}, \quad \mathrm{R}^{3}=\mathrm{H} \\
\mathrm{R}^{2}=\mathrm{Bzl}, \quad \mathrm{R}^{3}=\mathrm{H} \\
\mathrm{R}^{2}=\mathrm{R}^{3}=\mathrm{Bzl} \\
\mathrm{R}^{2}=\mathrm{Bzl}, \quad \mathrm{R}^{3}=\mathrm{H}\end{array}$ & \multicolumn{2}{|c|}{$\begin{array}{l}5: \mathrm{R}^{1}=\mathrm{BOC} \\
6: \mathrm{R}^{1}=\mathrm{H} \\
7: \mathrm{R}^{1}=\mathrm{H} \\
8: \mathrm{R}^{1}=\mathrm{H}\end{array}$} & \multicolumn{2}{|c|}{$\begin{array}{l}\mathrm{R}^{2}=\mathrm{Me}, \quad \mathrm{R}^{3}=\mathrm{H} \\
\mathrm{R}^{2}=\mathrm{R}^{3}=\mathrm{Me} \\
\mathrm{R}^{2}=\mathrm{Bz} \mathrm{l}, \quad \mathrm{R}^{2}=\mathrm{Me} \\
\mathrm{R}^{2}=\mathrm{All}, \quad \mathrm{R}^{3}=\mathrm{Me}\end{array}$} & \\
\hline & \multirow{2}{*}{$\operatorname{mp}_{\left({ }^{\circ} \mathrm{C}\right)}$} & \multirow{2}{*}{$\begin{array}{c}\text { Yield } \\
(\%)\end{array}$} & \multirow{2}{*}{$\begin{array}{l}\text { Recryst. } \\
\text { solvent }\end{array}$} & \multirow{2}{*}{$\begin{array}{l}{[\alpha]_{\mathrm{D}}^{\mathrm{t}}} \\
(c=1 \\
\text { solv. })\end{array}$} & \multirow{2}{*}{$\begin{array}{l}\mathrm{TLC} \\
R f_{1} \\
\left(R f_{2}\right)\end{array}$} & \multirow{2}{*}{ Formula } & \multicolumn{3}{|c|}{$\begin{array}{c}\text { Anal. } \\
\text { Calcd (Found) }\end{array}$} \\
\hline & & & & & & & $\mathrm{C}$ & $\mathrm{H}$ & $\mathrm{N}$ \\
\hline 1 & $148-150$ & 51 & $\begin{array}{l}\text { MeOH-ether- } \\
\text { petr. ether }\end{array}$ & $\begin{array}{c}-5^{15} \\
(\mathrm{MeOH})\end{array}$ & 0.27 & $\mathrm{C}_{6} \mathrm{H}_{11} \mathrm{NO}_{3} \mathrm{~S}$ & $\begin{array}{r}40.66 \\
(40.22\end{array}$ & $\begin{array}{l}6.26 \\
6.21\end{array}$ & $\begin{array}{l}7.90 \\
7.58)\end{array}$ \\
\hline 2 & $142-145$ & 60 & $\begin{array}{l}\mathrm{CHCl}_{3} \text {-ether- } \\
\text { petr. ether }\end{array}$ & $\begin{array}{l}-56^{16} \\
(\mathrm{MeOH})\end{array}$ & 0.32 & $\mathrm{C}_{12} \mathrm{H}_{15} \mathrm{NO}_{3} \mathrm{~S}$ & $\begin{array}{r}56.89 \\
(56.78\end{array}$ & $\begin{array}{l}5.97 \\
5.91\end{array}$ & $\begin{array}{l}5.52 \\
5.21)\end{array}$ \\
\hline 3 & $123-126$ & 88 & $\mathrm{CHCl}_{3}$-ether & $\begin{array}{c}-5^{32} \\
\left(\mathrm{CHCl}_{3}\right)\end{array}$ & 0.86 & $\mathrm{C}_{24} \mathrm{H}_{23} \mathrm{NO}_{3} \mathrm{~S}$ & $\begin{array}{r}71.09 \\
(70.81\end{array}$ & $\begin{array}{l}5.71 \\
5.66\end{array}$ & $\begin{array}{l}3.46 \\
3.51)\end{array}$ \\
\hline $4^{a)}$ & $93-95$ & 71 & $\begin{array}{l}\text { AcOEt- } \\
\text { petr. ether }\end{array}$ & $\begin{array}{l}-45^{24} \\
\text { (acetone) }\end{array}$ & 0.52 & & & & \\
\hline $5^{b)}$ & $125-126.5$ & 84 & MeOH-ether & $\begin{array}{c}+5^{16} \\
(\mathrm{MeOH})\end{array}$ & 0.64 & $\begin{array}{r}\mathrm{C}_{21} \mathrm{H}_{40} \mathrm{~N}_{2} \mathrm{O}_{4} \mathrm{~S} \\
\cdot \mathrm{H}_{2} \mathrm{O}\end{array}$ & $\begin{array}{r}60.54 \\
(60.69\end{array}$ & $\begin{array}{r}10.16 \\
9.78\end{array}$ & $\begin{array}{l}6.72 \\
6.38)\end{array}$ \\
\hline $6^{c)}$ & $146-148$ & 80 & $\mathrm{MeOH}$-ether & $\begin{array}{c}-9^{18} \\
(\mathrm{MeOH})\end{array}$ & $(0.45)$ & $\begin{array}{r}\mathrm{C}_{5} \mathrm{H}_{11} \mathrm{NO}_{2} \mathrm{~S} \\
\cdot \mathrm{HCl}\end{array}$ & $\begin{array}{r}32.35 \\
(32.15\end{array}$ & $\begin{array}{l}6.51 \\
6.38\end{array}$ & $\begin{array}{l}7.54 \\
7.35)\end{array}$ \\
\hline $7^{c, d)}$ & $150-152.5$ & 85 & $\mathrm{MeOH}$-ether & $\frac{-14^{18}}{\left(\mathrm{H}_{2} \mathrm{O}\right)}$ & $(0.73)$ & & & & \\
\hline $8^{c)}$ & $118.5-121$ & 61 & $\mathrm{MeOH}-\mathrm{ether}$ & $\begin{array}{c}+5^{15} \\
(\mathrm{MeOH})\end{array}$ & $(0.51)$ & $\begin{array}{r}\mathrm{C}_{7} \mathrm{H}_{13} \mathrm{NO}_{2} \mathrm{~S} \\
\cdot \mathrm{HCl}\end{array}$ & $\begin{array}{r}39.71 \\
(39.61\end{array}$ & $\begin{array}{l}6.66 \\
6.69\end{array}$ & $\begin{array}{l}6.61 \\
6.34)\end{array}$ \\
\hline
\end{tabular}
a) Lit. ${ }^{8}: \operatorname{mp} 99^{\circ},[\alpha]_{\mathrm{D}}^{26}-45.1^{\circ}(c=2$, acetone $)$.
b) DCHA salt.
c) $\mathrm{HCl}$ salt.
d) Lit. ${ }^{\text {) }}: \operatorname{mp~} 150^{\circ},[\alpha]_{\mathrm{D}}^{21}-13.9^{\circ}\left(c=2.9, \mathrm{H}_{2} \mathrm{O}\right)$.

強い相乗効果を示したセりン5) をシステイン誘導体とペプチドに組み込んだばあい，抗酸化性と抗酸化剂との相 乘作用にどのような変化が現われるか興味がもたれる。そこで Cys-Ser ないし Ser-Cys 配列のジペプチド誘導体 を合成しリノール酸の自動酸化ならびに $\propto$-Toc と BHT に対する相乗効果を検討した。

本報ではシステイン誘導体拉よびそれらとセリンのジペプチド誘導体の合成を報告する.

\section{システイン誘導体 $(1-8)$}

S-アルキルシステインないしそのェステルを常法に従いアセチル化するか, Schotten-Baumann 法によるアシ ル化によって化合物（1-5) を51-88\% の収率で結晶状に得た。

また，メチルエステル (6-8) は塩化チオニル法7)で対応する遊離酸より合成した. Table I にこれらの化合物 の恒数と元素分析值を示す.

\section{ジペプチド誘導体 $(9-20)$}

BOC- ないし Z-Cys(Bzl)-OH とアミノ成分 $[\mathrm{H}-\mathrm{Ser}-\mathrm{OMe}$ または H-Cys(Me)-OMe をそれぞれの塩酸塩より調 製】を $\mathrm{BCC}$ を用いる混合酸無水物法 (MA 法) ないし DCC 法でカップリン゙グして化合物 9, 10, 13 をそれぞれ 60-70\% 収率で合成した。ささらに 13 のけん化で遊離ペプチド 14 をその DCHA 塩として結晶状に得た，し かし同様の操作により 9 から 11 を得る試みは成功しなかった。 そこで，BOC-Cys(Bzl)-OH とセりンを直接 MA 法で縮合し，生成物をシリカゲルクロマトグラフィーで精製して 11 を得た。このものはついで酸処理によ り脱 BOC 化を行ない遊離ペプチド 12 に導いた，他方，Ser-Cys 配列のペプチド誘導体の調製においても，先 ず該当する酸成分とアミノ成分を MA 法でカップリングして完全保護ペプチド $(15,16)$ を得た後，けん化ない し酸処理によりそれぞれの部分保護ペプチド $(17-20)$ とした．以上の生成物はいずれも薄層クロマトグラフィー

7) M. Brenner, W. Huber, Helv. Chim. Acta, 36, 1109 (1953).

8) S. Goldschmidt, C. Jutz, Chem. Ber., 86, 1116 (1953).

9) R.A. Boissonnas, S. Guttmann, P.A. Jaquenoud, J.P. Waller, Helv. Chim. Acta, 58, 1491 (1955). 
TABLE II. Derivatives of Cysteinylserine $(\mathbf{9 - 1 2})$ and Cysteinylcysteine $(\mathbf{1 3}, \mathbf{1 4})$

$$
\begin{array}{ccll}
\mathrm{R}^{2} & \mathbf{9}: \mathrm{R}^{1}=\mathrm{BOC}, & \mathrm{R}^{2}=\mathrm{Bzl}, & \mathrm{R}^{3}=\mathrm{Me} \\
\mathrm{R}^{1} \text {-Cys-Ser-OR }(\mathbf{9 - 1 2}) & \mathbf{1 0}: \mathrm{R}^{1}=\mathrm{Z}, & \mathrm{R}^{2}=\mathrm{Bzl}, & \mathrm{R}^{3}=\mathrm{Me} \\
& \mathbf{1 1}: \mathrm{R}^{1}=\mathrm{BOC}, & \mathrm{R}^{2}=\mathrm{Bzl}, & \mathrm{R}^{3}=\mathrm{H} \\
& \mathbf{1 2}: \mathrm{R}^{1}=\mathrm{H}, & \mathrm{R}_{2}=\mathrm{Bzl}, & \mathrm{R}^{3}=\mathrm{H} \\
\mathrm{Me} \mathrm{Me} & & \\
\text { BOC-Cys-Cys-OR }(\mathbf{1 3}, \mathbf{1 4}) & \mathbf{1 3}: \mathrm{R}=\mathrm{Me} & & \\
& \mathbf{1 4}: \mathrm{R}=\mathrm{H} & &
\end{array}
$$

\begin{tabular}{|c|c|c|c|c|c|c|c|c|c|c|}
\hline \multirow{2}{*}{$\begin{array}{c}\text { Compd. } \\
\text { No. }\end{array}$} & \multirow{2}{*}{$\underset{\left({ }^{\circ} \mathrm{C}\right)}{\operatorname{mp}}$} & \multirow{2}{*}{$\begin{array}{l}\text { Yield } \\
(\%)\end{array}$} & \multirow{2}{*}{$\begin{array}{l}\text { Recryst. } \\
\text { solvent }\end{array}$} & \multirow{2}{*}{$\begin{array}{c}{[\alpha]_{\mathrm{D}}^{\mathrm{to}}} \\
(c=1 \\
\mathrm{MeOH})\end{array}$} & \multicolumn{2}{|c|}{ TLC } & \multirow{2}{*}{ Formula } & \multicolumn{3}{|c|}{$\begin{array}{c}\text { Anal. } \\
\text { Calcd (Found) }\end{array}$} \\
\hline & & & & & $R f_{1} R$ & $f_{2} R f_{3}$ & & $\mathrm{C}$ & $\mathrm{H}$ & $\mathrm{N}$ \\
\hline 9 & $43-45.5$ & 73 & $\begin{array}{l}\text { AcOEt-ether- } \\
\text { petr. ether }\end{array}$ & $-25^{14}$ & 0.45 & 0.83 & $\mathrm{C}_{19} \mathrm{H}_{28} \mathrm{~N}_{2} \mathrm{O}_{6} \mathrm{~S}$ & $\begin{array}{r}55.32 \\
(55.51\end{array}$ & $\begin{array}{l}6.84 \\
6.79\end{array}$ & $\begin{array}{l}6.79 \\
6.35)\end{array}$ \\
\hline $\mathbf{1 0}^{a)}$ & $107-110$ & 59 & $\begin{array}{l}\text { AcOEt- } \\
\text { petr. ether }\end{array}$ & $-30^{23}$ & & 0.75 & $\mathrm{C}_{22} \mathrm{H}_{26} \mathrm{~N}_{2} \mathrm{O}_{6} \mathrm{~S}$ & $\begin{array}{r}59.18 \\
(58.90\end{array}$ & $\begin{array}{l}5.87 \\
5.74\end{array}$ & $\begin{array}{l}6.27 \\
6.10)\end{array}$ \\
\hline $10^{b)}$ & $105-107.5$ & 36 & $\begin{array}{l}\text { AcOEt- } \\
\text { petr. ether }\end{array}$ & $-29^{23}$ & & 0.75 & & & & \\
\hline 11 & $93-98$ & 40 & $\begin{array}{l}\text { AcOEt- } \\
\text { petr. ether }\end{array}$ & $-16^{14}$ & 0.43 & 0.14 & $\mathrm{C}_{18} \mathrm{H}_{26} \mathrm{~N}_{2} \mathrm{O}_{6} \mathrm{~S}$ & $\begin{array}{r}54.25 \\
(53.96\end{array}$ & $\begin{array}{l}6.58 \\
6.50\end{array}$ & $\begin{array}{l}7.03 \\
6.75)\end{array}$ \\
\hline $12^{c)}$ & $98-102$ & 95 & MeOH-ether & $+13^{14}$ & \multicolumn{2}{|c|}{0.60} & $\begin{array}{r}\mathrm{C}_{13} \mathrm{H}_{18} \mathrm{~N}_{2} \mathrm{O}_{4} \mathrm{~S} \\
\cdot \mathrm{HCl}\end{array}$ & $\begin{array}{r}46.63 \\
(46.63\end{array}$ & $\begin{array}{l}5.72 \\
6.08\end{array}$ & $\begin{array}{l}8.36 \\
7.88)\end{array}$ \\
\hline 13 & $106-107.5$ & 66 & $\begin{array}{c}\mathrm{CHCl}_{3} \text {-ether- } \\
\text { petr. ether }\end{array}$ & $-54^{18}$ & 0.75 & 0.74 & $\mathrm{C}_{14} \mathrm{H}_{26} \mathrm{~N}_{2} \mathrm{O}_{5} \mathrm{~S}_{2}$ & $\begin{array}{r}45.88 \\
(45.96\end{array}$ & $\begin{array}{l}7.15 \\
6.94\end{array}$ & $\begin{array}{l}7.64 \\
7.37)\end{array}$ \\
\hline $\mathbf{1 4}^{d)}$ & $121-125$ & 52 & AcOEt-ether & $-28^{19}$ & 0.53 & 0.31 & $\mathrm{C}_{25} \mathrm{H}_{47} \mathrm{~N}_{2} \mathrm{O}_{5} \mathrm{~S}_{2}$ & $\begin{array}{r}55.84 \\
(55.68\end{array}$ & $\begin{array}{l}8.88 \\
8.69\end{array}$ & $\begin{array}{l}7.87 \\
7.36)\end{array}$ \\
\hline
\end{tabular}

a) Prepared by DCC method. b) Prepared by MA method. c) $\mathrm{HCl}$ salt. d) DCHA salt.

TABLE III. Serylcysteine Derivatives (15-20)

\begin{tabular}{|c|c|c|c|c|c|c|c|c|c|c|}
\hline \multirow{2}{*}{$\begin{array}{l}\text { Compd. } \\
\text { No. }\end{array}$} & \multirow{2}{*}{$\underset{\left({ }^{\circ} \mathrm{C}\right)}{\operatorname{mp}}$} & \multirow{2}{*}{$\begin{array}{l}\text { Yield } \\
(\%)\end{array}$} & \multirow{2}{*}{$\begin{array}{c}\text { Recryst. } \\
\text { solvent }\end{array}$} & \multirow{2}{*}{$\begin{array}{c}{[\alpha]_{\mathrm{D}}^{+\alpha}} \\
(c=1, \\
\mathrm{MeOH})\end{array}$} & \multicolumn{2}{|c|}{ TLC } & \multirow{2}{*}{ Formula } & \multicolumn{3}{|c|}{$\begin{array}{l}\text { Aanl. } \\
\text { Calcd (Found) }\end{array}$} \\
\hline & & & & & $R f_{1}$ & $R f_{3}$ & & $\mathrm{C}$ & $\mathrm{H}$ & $\mathrm{N}$ \\
\hline 15 & $58.5-61$ & 73 & $\begin{array}{l}\text { AcOEt- } \\
\text { petr. ether }\end{array}$ & $-56^{13}$ & 0.38 & 0.65 & $\mathrm{C}_{19} \mathrm{H}_{28} \mathrm{~N}_{2} \mathrm{O}_{6} \mathrm{~S}$ & $\begin{array}{r}55.32 \\
(54.80\end{array}$ & $\begin{array}{l}6.84 \\
6.81\end{array}$ & $\begin{array}{l}6.79 \\
6.39)\end{array}$ \\
\hline 16 & $119-121.5$ & 56 & $\begin{array}{l}\text { AcOEt- } \\
\text { petr. ether }\end{array}$ & $-44^{23}$ & 0.56 & 0.79 & $\mathrm{C}_{28} \mathrm{H}_{30} \mathrm{~N}_{2} \mathrm{O}_{6} \mathrm{~S}$ & $\begin{array}{r}64.06 \\
(63.54\end{array}$ & $\begin{array}{l}6.22 \\
5.69\end{array}$ & $\begin{array}{l}5.34 \\
5.44)\end{array}$ \\
\hline 17 & $115-120$ & 74 & $\begin{array}{l}\text { AcOEt- } \\
\text { petr. ether }\end{array}$ & $-19^{13}$ & 0.42 & 0.05 & $\begin{array}{r}\mathrm{C}_{1 \mathrm{~s}} \mathrm{H}_{26} \mathrm{~N}_{2} \mathrm{O}_{6} \mathrm{~S} \\
\cdot 1 / 2 \mathrm{H}_{2} \mathrm{O}\end{array}$ & $\begin{array}{r}53.06 \\
(53.04\end{array}$ & $\begin{array}{l}6.68 \\
6.39\end{array}$ & $\begin{array}{l}6.87 \\
6.68)\end{array}$ \\
\hline 18 & $136-138.5$ & 59 & $\begin{array}{l}\text { AcOEt- } \\
\text { petr. ether }\end{array}$ & $-16^{18}$ & 0.29 & & $\begin{array}{r}\mathrm{C}_{21} \mathrm{H}_{24} \mathrm{~N}_{2} \mathrm{O}_{6} \mathrm{~S} \\
\cdot 1 / 2 \mathrm{H}_{2} \mathrm{O}\end{array}$ & $\begin{array}{r}57.13 \\
(56.59\end{array}$ & $\begin{array}{l}5.71 \\
5.62\end{array}$ & $\begin{array}{l}6.35 \\
6.14)\end{array}$ \\
\hline $19^{a)}$ & $124-125.5$ & 50 & MeOH-ether & $-42^{13}$ & 0.08 & 0.25 & $\begin{array}{l}\mathrm{C}_{14} \mathrm{H}_{20} \mathrm{~N}_{2} \mathrm{O}_{4} \mathrm{~S} \\
\cdot \mathrm{HCl} \cdot 1 / 2 \mathrm{H}_{2} \mathrm{O}\end{array}$ & $\begin{array}{r}46.99 \\
(46.91\end{array}$ & $\begin{array}{l}6.20 \\
5.86\end{array}$ & $\begin{array}{l}7.83 \\
7.65)\end{array}$ \\
\hline $\mathbf{2 0}^{a)}$ & $100-104$ & 93 & MeOH-ether & $-31^{14}$ & & & $\begin{array}{r}\mathrm{C}_{13} \mathrm{H}_{18} \mathrm{~N}_{2} \mathrm{O}_{4} \mathrm{~S} \\
\cdot \mathrm{HCl}\end{array}$ & $\begin{array}{r}46.63 \\
(46.60\end{array}$ & $\begin{array}{l}5.72 \\
6.06\end{array}$ & $\begin{array}{l}8.36 \\
7.82)\end{array}$ \\
\hline
\end{tabular}

$\begin{array}{clll} & 15: R^{1}=B O C, & R^{2}=B z l, & R^{3}=M e \\ & 16: R^{1}=Z, & R^{2}=B z l, & R^{3}=B z l \\ R^{2} & 17: R^{1}=B O C, & R^{2}=B z l, & R^{3}=H \\ R^{1} \text { Ser-Cys-OR } & 18: R^{1}=Z, & R^{2}=B z l, & R^{3}=H \\ & 19: R^{1}=H, & R^{2}=B z l, & R^{3}=M e \\ & 20: R^{1}=H, & R^{2}=B z l, & R^{3}=H\end{array}$

a) $\mathrm{HCl}$ salt.

(TLC) 上単一スポットを与えた. Table II, III にこれらの化合物の融点, 旋光度, TLC, 元素分析値を示す.

以上合成した各化合物のリノール酸の自動酸化に対する抗酸化能および BHTないし $\alpha$-Toc との相乗効果につ いては別に報告する.5) 


\section{実験 の 部}

融点は未補正. $[\alpha]_{\mathrm{D}}$ は Jasco DIP-SL 型旋光計で測定. TLC は Kieselgel G (Merck) プレート上 $\mathrm{CHCl}_{3}$ $\mathrm{MeOH}-\mathrm{AcOH} \quad\left(95: 5: 3, R f_{1}\right) \quad n-\mathrm{BuOH}-\mathrm{AcOH}-\mathrm{H}_{2} \mathrm{O}$ (4:1:5 上層, $\left.R f_{2}\right)$ 特よび $\mathrm{CHCl}_{3}-\mathrm{MeOH}$ ピリジン

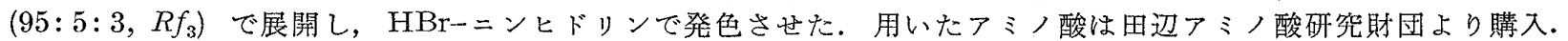
S-methyl cysteine は Sigma, S-allyl cysteine は NBC, S-benzyl cysteine はペプチド研究所の各製品を使用. $\alpha-$ アミノ酸は全て L 型を使用乙, 略名は IUPAC-IUB 生化学命名委員会 (J.Biol.Chem., 247.977 (1972)) 飞 従った。使用した略号：BCC = isobutyl chloroformate, DCC = dicyclohexylcarbodiimide, DMF $=$ dimethylformamide, $\mathrm{THF}=$ tetrahydrofuran, $\mathrm{DCHA}=$ dicyclohexylamine, $\mathrm{Bz}=$ benzoyl, $\mathrm{All}=$ allyl.

Ac-Cys $(\mathbf{M e})-\mathbf{O H}(\mathbf{1}) \quad$ S-Methyl cysteine $0.27 \mathrm{~g}$ を $\mathrm{Ac}_{2} \mathrm{O}+\mathrm{AcOH}(1: 1)$ 混液 $4 \mathrm{ml}$ 飞溶かし, $3 \mathrm{hr}$ 放置, 溶 媒を留去して 1 の結晶残椬を得る (Table I).

Ac-Cys(Bzl)-OH (2) S-Benzyl cysteine $1.06 \mathrm{~g}$ を $3.5 \mathrm{~N} \mathrm{NaOH} 18 \mathrm{ml}$ と $5 \% \mathrm{NaHCO}_{3} 60 \mathrm{ml}$ の混液に溶 汃し，攪汼下 $\mathrm{Ac}_{2} \mathrm{O} 8 \mathrm{ml}$ を滴加，1.5 hr 攪拌後 $9 \mathrm{~N} \mathrm{H}_{2} \mathrm{SO}_{4}$ を加えて酸性としェーテル抽出 $(30 \mathrm{ml} \times 3)$, 抽出液 を水洗, $\mathrm{MgSO}_{4}$ で乾燥し, 溶媒を留去すると 2 の結晶を得る(Table I).

Bz-Cys (Bzl)-OBzl (3) H-Cys(Bzl)-OBzl·Tos OH ${ }^{10)} 4.7 \mathrm{~g}$ をピリジン $19 \mathrm{ml}$ に溶かし, 氷冷下靦拌しつつ $\mathrm{BzCl} 2.5 \mathrm{ml}$ を滴下し, 室温で $2.5 \mathrm{hr}$ 擤抖, 反応液を水水 $30 \mathrm{ml}$ に注加し, 析出結晶をろ取, $1 \mathrm{~N} \mathrm{HCl}$, 水で洗 浄, 乾燥 (Table I).

I).

Z-Cys (BzI)-OH (4) S-Benzyl cysteine を常法に従い，アルカリ条件下 Z-Cl と反応して Z 化した (Table

BOC-Cys(Me)-OH·DCHA (5) S-Methyl cysteine $2.7 \mathrm{~g}$ をジオキサン $11 \mathrm{ml}$, 水 $11 \mathrm{ml}, \mathrm{Et} \mathrm{t}_{3} \mathrm{~N} 3.8 \mathrm{ml}$ の混液 溶かし S-t-butyloxycarbonyl-4,6-dimethyl-2-mercaptopyrimidine ${ }^{11)} 5.3 \mathrm{~g}$ を加觉室温で 1 日攪抖，水 $30 \mathrm{ml}$ を加光 $\operatorname{AcOEt}(25 \mathrm{ml} \times 2)$ 抽出, 水層を承冷下 $5 \mathrm{~N} \mathrm{HCl}$ で $\mathrm{pH} 2$ となし $\mathrm{AcOEt}(50 \mathrm{ml} \times 2)$ 抽出, AcOEt 層 を $1 \mathrm{~N} \mathrm{HCl}$ ，水で洗い $\mathrm{MgSO}_{4}$ で乾燥し溶媒を留去，油状残渣をェーテルに溶かし DCHA を加えると結晶析出 (Table I).

H-Cys $(\mathbf{R})$-OMe. $\mathrm{HCl}(6-8 \cdot \mathbf{H C l})$; 一般法 (Table I) 無水 $\mathrm{MeOH} 1.1 \mathrm{ml}$ を - $10^{\circ}$ に冷却し, $\mathrm{SOCl}_{2} 0.25 \mathrm{ml}$

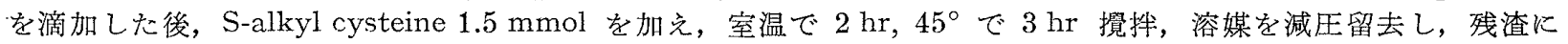
無水 $\mathrm{MeOH} 10 \mathrm{ml}$ を加兄再び濃縮する. 残椬に無水 $\mathrm{MeOH}$ を加光濃縮する操作をさらに 2 回繰り返して生成 物の結晶を得た。

N-保護ジペプチドエステル $(9,10,13,15,16)$ (Table II，III) (i) MA 法（一般法)一一既報 ${ }^{12)}$ の方法に よって行ない, $9,10,13,15,16$ を得た。

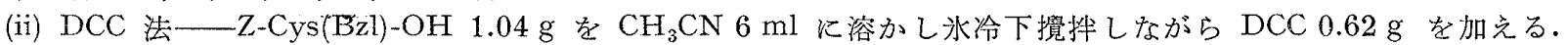
これへ $\mathrm{H}-\mathrm{Ser}-\mathrm{OMe} \cdot \mathrm{HCl}$ と $\mathrm{Et}_{3} \mathrm{~N} 0.42 \mathrm{~g}$ を含む $\mathrm{CH}_{3} \mathrm{CN}$ 溶液 $4.5 \mathrm{ml}$.を滴加し $10 \mathrm{~min}$ 間, ついで室温で 1 夜

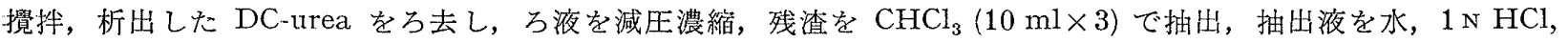
$5 \% \mathrm{NaHCO}_{3}$, 水で洗い, $\mathrm{MgSO}_{4}$ で乾燥, 溶媒を留去し, 残椬にエーテルを加えると 10 が結晶化.

$\mathbf{N}$-保護ジペプチド $(\mathbf{1 1}, \mathbf{1 4}, \mathbf{1 7}, \mathbf{1 8})$ (Table II, III) (i) 直接縮合—BOC-Cys(Bzl)-OH $1.24 \mathrm{~g}$ と Et ${ }_{3} \mathrm{~N} 0.56$ $\mathrm{ml}$ を乾燥 THF $8 \mathrm{ml}$ 飞溶かし，攪䢁下 BCC $0.52 \mathrm{ml}$ を加える.ついでせりン $0.53 \mathrm{~g}$ Et $\mathrm{H}_{3} \mathrm{~N} 0.56 \mathrm{ml}$ を溶

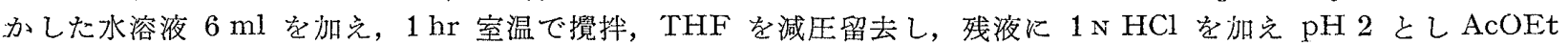
$(25 \mathrm{ml} \times 2)$ で抽出, 抽出液を水洗, 乾燥後溶媒留去, 油状残渣を $\mathrm{CHCl}_{3}-\mathrm{MeOH}-\mathrm{AcOH}(95: 5: 3)$ を溶媒とする カラムクロマトグラフィー (Kiesel gel 70-325 mesh, 30×300 mm) にかけ, 溶出液の HBr-ニンヒドリン陽性画 分を集めた。溶媒を減圧留去, 油状残渣を石油エーテルで処理し，11 の結晶を得た。

(ii) $\mathrm{N}$-保護ジペプチドェステルのけん化（一般法）—- N-保護ジペプチドェステル $0.8 \mathrm{mmol}$ を $\mathrm{MeOH} 1 \mathrm{ml}$

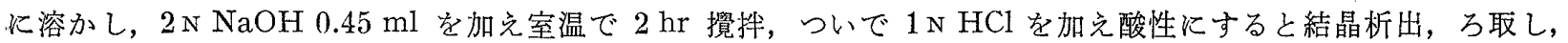
水洗, 乾燥. 生成物が油状の時には $\mathrm{MeOH}$ を隇圧留去し，エーテル抽出 $(30 \mathrm{ml} \times 2)$, 抽出液を水洗, $\mathrm{MgSO}_{4}$ で乾燥, 溶媒を留去し, 残榃を少量のエーテルに溶かし DCHA を加光結晶化。

$\mathrm{H}-\mathrm{Cys}(\mathrm{Bzl})-\mathrm{Ser}-\mathrm{OH} \cdot \mathrm{HCl}(\mathbf{1 2} \cdot \mathbf{H C l}) \quad 110.4 \mathrm{~g}$ を乾燥 $\mathrm{CHCl}_{3} 1.2 \mathrm{ml}$ 飞溶かし, $4.3 \mathrm{~N} \mathrm{HCl-ジオキサン} 1.2 \mathrm{ml}$ を加え室温で $15 \mathrm{~min}$ 間靦抖, 減殴濃縮し残渣にェーテルを加えると結晶析出, ろ取しェーテルで洗浄 (Table II). 同様の方法で 15, 17 を処理し，それぞれ 19 と 20 の $\mathrm{HCl}$ 塩を得た (Table III).

謝辞元素分析を担当された金沢大学薬学部中央分析室板谷芳京, 豊島佐智子両氏に感謝する.

10) L. Zervas, M.Winitz, J.P. Greenstein, J. Org. Chem., 22, 1515 (1957).

11) T. Nagasawa, K. Kuroiwa, K. Narita, Y. Isowa Bull. Chem. Soc. Jpn. 46, 1269 (1973).

12）岡田幸蔵, 川瀬正之, 竹内良一, 永井外夫, 薬誌, 96, 1038 (1976). 